\title{
English Learning for Folklore Maintenance in Pekalongan Tourism
}

\author{
Cut Aja Puan Ellisafny ${ }^{1}$, Christine Resnitriwati ${ }^{2}$ \\ \{cpuanellysafny@gmail.com\} \\ English Department, Faculty of Humanities, Diponegoro University, \\ Semarang, 50275, Indonesia ${ }^{1,2}$
}

\begin{abstract}
This research aims to conduct the folklore-based English learning for the Pekalongan local tourism development. The role of folklore in the tourism development is very significant to improve the English competence for the tourism actors in Pekalongan. The research theories and methods used are the pre-research stage by conducting a preliminary study regarding the inventory of folklore in Pekalongan containing the potential material of learning English for the tourism development. The field research stage for the data collection is conducted with the interview method while the data processing stage is performed by conducting a folklore learning training of the English learning material. This research is expected to be a folklore-based English learning model for the tourism development that can be applied to empower the tourism villages in the Pantura Region in accordance with the master plan for development of Diponegoro University. In conclusion, the folklore-based English learning can be well accepted by the participants since the learning materials are suitable to the local wisdom of the Pekalongan people and are in accordance with the participants' level of competence. Besides, the materials can motivate the Pekalongan tourism actors to promote the Pekalongan tourism to the outside world as well. Indeed, composing a folklore-based learning module is needed so that the local tourism can be developed thoroughly.
\end{abstract}

Keywords: Folklore-based English; english learning; tourism; Pekalongan.

\section{Introduction}

This research is entitled "English Learning for Folklore Maitenance in Pekalongan Tourism." Studying folklore is an object of local literary research that is still very open and has not been widely used in applied research. This study aims to implement learning-based English folklore for the development of tourism in Pekalongan which can be useful for the maintenance of folklore in local tourism. Besides, it can empower the local tourism actors to be able to attract and increase foreign tourist visits to Pekalongan tourism.

Pekalongan City is chosen as a learning target. This city is known as the city of Santri and has a lot of local wisdom that can be designated as the insertion of teaching materials. Besides that, Pekalongan City also has folktales that are not yet known to many people. By raising folklore for learning English, elements of local culture can continue to be known.

The theoretical foundation used in this study refers to James Dananjaya, Foklor Indonesia (1984), Suwardi Endraswara, Metodologi Penelitian Folklor (2009). Local wisdom has various forms and can be realized in the form of clothing, food, authentic artifacts, music, dance, films, etc. [1]. Local wisdom can also be found in languages in the form of wise words, proverbs, songs, or narratives such as folklore, myths, legends, regional cuisine, etc. The first 
narrative was an oral tradition containing local wisdom such as philosophy, norms, and behavior.

To improve the quality of education and the quality of teaching, it is necessary to pay attention to the process of developing teaching materials and making teaching material frameworks. Graves in Faridi (59-60) states that there are several things that become references in developing teaching materials, including finding the material needed for students, determining learning goals, selecting and developing material, determining the content and activities of activities in the classroom, doing evaluation of learning, as well as paying attention to the constraints and related reading resources.

Teaching materials used in the learning process vary, including those in the form of textbooks and some in the form of visuals. In general, teaching materials that are most widely used by teachers as supporting learning in the classroom are textbooks. There are two types of textbooks revealed by Cunningsworth [2] namely traditional textbooks and communicative textbooks.

\section{Method}

The two methods of folklore research used are speculative empirical and subjective methods of speculation (Dundes, 70). The pre-research stage is carried out by using a library research method about folktales in Pekalongan. The field research stage for data collection began by interviewing the Pekalongan Tourism Office, local communities and local tourism actors in Pekalongan as well. The data processing stage is done by designing folklore as an English learning module for Pekalongan Tourism Ambassador Participants for local tourism development. The output stage of the study is carried out by writing articles for international seminars and publications in proceedings. And in the final stage, the writing of the research report.

In conducting research and development, the research team used several methods, including descriptive, evaluative, and experimental methods. The communicative method is used for teaching English in the form of pair work (in pairs) or group work (in groups). In addition, the method of interviewing between learning participants and the speakers was also used. Evaluative methods are used to evaluate trials of developing teaching materials that integrate folklore. Teaching material was developed through trials, and trials were conducted to evaluate the strengths and weaknesses of the product. From the results of the evaluation, improvements can be made to the teaching material.

\section{Results and Discussions}

The participants who took part in this study were 22 Tourism Ambassador Candidates in Pekalongan City, the topic of local wisdom in Pekalongan was raised to be very relevant considering that prospective tourism ambassadors would promote Pekalongan culture as the main attraction. Participants, who graduated from high school, have various educational backgrounds such as businessman, bank clerk, government officials, etc. This condition makes it easy to choose teaching materials to fit the learning skills of the English participants.

English language training is given in 2 different types of productive skills, namely Writing and Speaking. The training was attended by 22 Tourism Ambassador Candidates in Pekalongan City, so that the topic of local wisdom in Pekalongan was claimed to be very relevant, considering that prospective tourism ambassadors would promote Pekalongan culture as the main attraction of the outside world [3] 
The writing evaluation results show that the majority of participants still have difficulty in determining the form of To Be that must be used and the Past Participle forms that need to be used. Given the basic concept of using passive sentences is the use of To Be + Past Participle. It can be seen from the results of the evaluation that participants still experience difficulties when required to use the Past Participle of irregular verbs. This shows that the learning participants still need to be given guidance that focuses on the use of the Past Participle of irregular verbs and how to determine the To Be form that must be used in passive sentences.

Evaluation of the results of the speaking learning was carried out by an interview system, where participants were asked by the examiner to mention what materials were used to cook Pekalongan Tauto and how to cook it. At the end of the training participants were given a review of their abilities in English based on the materials given during the training, such as describing objects then how to cook and present and briefly retell the history of a culinary experience. The review topic in this training was about giant Lopis presented in the Syawalan tradition. This review runs from 12:00 to 14:00.

The evaluation results show that 10 out of 22 participants have been able to convey cooking instructions using English well. However, there are still some minor deficiencies such as the use of affixes-s / -es for plural objects. Each participant is observed for his ability and given a value in this review.

From the evaluation above, we can average the ability of the trainees as a whole, namely from the number of scores divided by the number of trainees, namely 1460 divided by 22 . So the participant's ability on average is 66,036 . In addition, some participants seemed still nervous about conveying their thoughts, and some still had limited vocabulary. This of course can hinder the development of their English language skills if they are not honed, so it is expected that this learning can add to the experience of participants as ambassadors of Pekalongan tourism in developing their English language skills.

In addition to evaluations based on assessment, researchers also conducted material evaluations using a questionnaire. Based on the results of the questionnaire the majority of students said that this learning provides new information and knowledge in reading and writing folklore in Pekalongan. This is due to the lack of knowledge about Pekalongan's original folklore and the lack of people who speak the original Pekalongan folklore using English. The majority of students also agreed that the material provided was suitable for learning to write and read folklore in English for the ambassador of Pekalongan tourism. Students also felt the need to insert Pekalongan folklore in learning because it was considered beneficial to them as ambassadors of Pekalongan tourism in promoting Pekalongan tourism to foreign tourists. This also causes students to support more English writing learning.

\section{Conclusion}

The process of folklore-based English learning can be accepted by participants due to the reasons as follow: This topic is familiar with the local wisdom of Pekalongan people. The material provided is in accordance with the competency level of the participants and can motivate Pekalongan tourism actors to promote Pekalongan tourism. It is necessary to develop folklore material for the preparation of learning modules to increase regional tourism.

\section{References}


[1]. Barfield, S., \& Uzarski, J. Integrating Indigenous Cultures into English Language Teaching. 2009 Number 1 English Teaching Forum (2009)

[2]. Cunningsworth, A. Evaluating and Selecting EFL Teaching Materials. London: Hainemann (1984) Dundes, Alan, Ed. The Study of Folklore. Upper Saddle River, NJ: Prentice Hall (1965)

[3]. Nunan, David. Designing Tasks for the Communicative Classroom. Cambridge University Press, Print (1990). 